\title{
Notre Dame Cathedral: Another Case in a Growing List of Heritage Landmarks Destroyed by Fire
}

\author{
Tiago Miguel Ferreira \\ ISISE, Institute of Science and Innovation for Bio-Sustainability (IB-S), Department of Civil Engineering, \\ University of Minho, 4800-058 Guimarães, Portugal; tmferreira@civil.uminho.pt
}

Received: 17 April 2019; Accepted: 23 April 2019; Published: 24 April 2019

16 April 2019. After a more than twelve-hour battle involving 600 firefighters [1], the massive blaze that has destroyed much of the timber roof and toppled the Gothic spire of the Notre Dame Cathedral is fully extinguished. The official cause of the fire is still being investigated, but it seems likely that it may have resulted from restoration works taking place in the 850-year-old structure. After surviving the French Revolution and Nazi occupation during World War II, Notre Dame Cathedral, a masterpiece of Gothic architecture, succumbed to a blaze. As if this were not enough, a large number of extraordinary works of art, musical instruments, statues, woodworks, and religious relics, the full list of which is available on the Cathedral's website [2], may also have been lost, not only due to the heat but also in consequence of the enormous quantities of water used to fight the fire.

Even though it may be premature to draw any conclusions regarding this specific case, it is worth reflecting on the fact that Notre Dame Cathedral is just another entry in a long list of cultural heritage landmarks that have been, wholly or partially, tragically destroyed by fire. Among many other significant examples, such as Windsor Castle, York Minster, the Venice and Barcelona opera houses, and Bosnia's National Library, it is impossible not to make note here of the National Museum of Brazil, which was ravaged by a huge fire on the night of 2 September 2018. Although some items were saved, the early nineteenth-century building was completely destroyed, in addition to more than $90 \%$ of its archive of 20 million items [3], including its Egyptology collection, which was one of the largest in Latin America, and some of the oldest human remains ever found in the Americas.

Particular attention should be paid, however, to a significant number of heritage buildings that, as in the case of Notre Dame Cathedral, have been lost to fire during restoration and construction processes. Exact numbers are difficult to obtain, but estimates suggest that about $10 \%$ of fires in heritage buildings do occur when contractors are present [4]. In most of these cases, fires were caused by hot works (welding and cutting, etc.), which, in light of the material and constructive characteristics of heritage buildings, which include plenty of voids and ducts where fire can spread, are particularly dangerous. A striking example is the National Trust's Uppark House. In August 1989, this seventeenth-century building was devastated by a fire caused by a workman's blowtorch which was being used to repair lead flashing on the roof [5].

Another paradigmatic case is the Mackintosh library at the Glasgow School of Art, one of the world's finest examples of art nouveau design, which, in June 2018, was gutted by a fire when the structure was being restored following a previous fire which had occurred in May 2014. The library, which housed original furniture and fittings designed by Charles Rennie Mackintosh, was reduced to blackened rubble. The construction company responsible for the $£ 35 \mathrm{~m}$ restoration works stated that, despite there being no operational sprinklers at the site, a fire strategy including a smoke and heat detection system, round-the-clock security and fire patrols had been in place for the renovation and reconstruction [6,7]. In spite of this, the 110-year-old building was almost entirely destroyed.

These examples, selected from many that might have been added, should be a call to all professionals who are directly and indirectly involved in the preservation of cultural heritage buildings. 
Lessons must be learned from the Notre Dame fire, particularly those concerning fire safety during restoration and construction works. If it is true that all construction sites are inherently dangerous places, this danger is much higher within a heritage building context. In order to mitigate this, an effective fire management strategy, which should include, for example, the implementation of a reliable fire detection system and the demarcation of different working zones aimed at separating hot works from flammable materials, should be complemented by effective temporary fire protection systems, which, in the case of fire, must be able to effectively limit fire spread, while preserving the building and its contents. Regarding the latter recommendation, however, further research is needed to address the issues arising from the application of conventional solutions, such as sprinklers, high-pressure misting fire suppression systems, or Halon Gas extinguishers, in these restoration and construction works.

For the moment, it is unknown if any additional fire prevention measures were in place due to the restoration works in the Notre Dame Cathedral. It seems clear, however, that the new fire hazards introduced to the ancient structure, which was built at a time in which there were no fire protection codes, and that is itself a source of combustible material, resulted in the partial destruction of one of the most iconic heritage buildings in the world.

Conflicts of Interest: The author declares no conflict of interest.

\section{References}

1. Incendie à Notre-Dame de Paris. L'actu du Ministère, Ministère de l'Intérieur (France). Available online: https://www.interieur.gouv.fr/Actualites/L-actu-du-Ministere/Incendie-a-Notre-Dame-de-Paris (accessed on 20 April 2019).

2. The masterpieces of Notre-Dame. Available online: http://www.notredamedeparis.fr/en/la-cathedrale/ linterieur/ (accessed on 16 April 2019).

3. Bazil's national museum hit by huge fire. $B B C$ News. Available online: https://www.bbc.com/news/worldlatin-america-45392668 (accessed on 16 April 2019).

4. Kidd, S. Fire Safety Management in Historic Buildings; Historic Scotland: Edinburgh, UK, 2005; ISBN 190496611X.

5. The Fire at Uppark. Available online: https://www.nationaltrust.org.uk/uppark-house-and-garden/features/ the-fire-at-uppark (accessed on 16 April 2019).

6. How do you recreate a masterpiece like the Mackintosh Library? BBC News. Available online: https: //www.bbc.com/news/uk-scotland-41205642 (accessed on 16 April 2019).

7. Glasgow School of Art: Sprinklers had not been fitted after first fire. BBC News. Available online: https://www. theguardian.com/education/2018/jun/17/glasgow-school-of-art-fire-rennie-mackintosh-sprinklers (accessed on 16 April 2019).

(C) 2019 by the author. Licensee MDPI, Basel, Switzerland. This article is an open access article distributed under the terms and conditions of the Creative Commons Attribution (CC BY) license (http://creativecommons.org/licenses/by/4.0/). 